\title{
PENGARUH LABA AKUNTANSI DAN ARUS KAS OPERASI TERHADAP HARGA SAHAM
}

\author{
Neng Asiah ${ }^{1)}$, Yeni Sri Mulyani ${ }^{2}$ \\ Universitas Pelita Bangsa, Program Studi Akuntansi \\ neng.asiah@pelitabangsa.ac.id
}

\begin{abstract}
ABSTRAK
Penelitian ini bertujuan untuk mengetahui Pengaruh Laba Akuntansi dan Arus Kas Operasi terhadap Harga Saham pada perusahaan Aneka Industri yang terdaftar di bursa efek indonesia (BEI) tahun 2015-2017. Metode yang digunakan dalam penelitian ini adalah metode kuantitatif. Teknik pengambilan sampel yang digunakan adalah purposive sampling dengan cara pengambilan sample menggunakan kriteria tertentu. Data sekunder yang diambil untuk penelitian ini berupa data akuntansi laporan keuangan perusahaan Aneka Industri di bursa efek indonesia (BEI) tahun 20152017. Penelitian ini menggunakan beberapa pengujian, diantaranya pengujian secara parsial (Uji t), pengujian secara simultan (Uji F) dan analisis regresi linier berganda. Hasil penelitian menggunakan uji parsial (t) menunjukan bahwa Laba Akuntansi (X1) tidak berpengaruh terhadap Harga saham (Y) sedangkan Arus Kas Operasi (X2) berpengaruh terhadap harga saham (Y). Sedangkan dengan (Uji F) Variabel Laba Akuntansi dan Arus Kas Operasi secara bersama-sama tidak berpengaruh terhadap Harga saham (Y) pada perusahaan Aneka Industri di bursa efek indonesia (BEI) tahun 2015-2017.
\end{abstract}

Kata Kunci: Laba Akuntansi, Arus Kas Operasi, Harga Saham

\begin{abstract}
This study aims to determine the effect of Accounting profit and operating cash flows on stock prices on various industrial companies listed on the Indonesia Stock. Exchange (IDX) in 2015-2017. The method used in this study is a quantitative method. The sampling technique used was purposive sampling by taking samples using certain criteria. Secondary data taken for this study are accounting data of various industrial financial reports on the indonesia Stock Exchange (IDX) in 2015-2017. This study uses several test, inculding partial testing (t test), simultaneous testing (Test F) and multiple linear regression analysis. The result of the study using partial test $(t)$ shows that Accounting profit (X1) does not affect on stock price (Y) while the operating cash flows (X2) affect on stock price (Y). Whereas with (Test F) accounting profit variables and operating cash flows together do not have influence on stock price $(Y)$ on various industrial companies listed on the Indonesia Stock Exchange (IDX) in 2015-2017.
\end{abstract}

Keyword : Accounting Profit, Operating cash flows, stock prices

\section{PENDAHULUAN}

Memasuki era globalisasi dan pasar bebas, persaingan usaha yang terjadi akan semakin kompleks dan ketat. Perusahaan perlu mengembangkan strategi untuk mempertahankan ekstensinya diantaranya melakukan ekspansi. Ekspansi adalah aktivitas memperluas usaha yang di tandai dengan penciptaan pasar baru dan perluasan modal. Oleh karena itu, Ekspansi dapat dilakukan dengan menjual surat utang atau menjual saham.

Perkembangan dunia yang semakin meningkat seiring dengan majunya teknologi informasi. Semakin menambah tingkat persaingan perusahaan dalam memperoleh keuntungan. Investasi pada hakikatnya merupakan penempatan sejumlah dana pada saat ini dengan harapan untuk memperoleh keuntungan di masa depan. Pihak investor dalam melakukan investasi tentunya mempertimbangkan resiko atas dana yang mereka investasikan. Prospek keuntungan yang di harapkan dapat diperkirakan dengan melihat harga saham yang selalu naik turun dan informasi akuntansi yang dikeluarkan oleh perusahaan.

Menurut (Untung, 2011) secara teoretis pasar modal (capital market) didefinisikan sebagai perdagangan instrumen keuangan (sekuritas) jangka panjang, baik dalam bentuk modal sendiri (stock) maupun hutang (bonds), baik yang diterbitkan oleh pemerintah (public authorities) maupun 
oleh perusahaan swasta (private sectors). Dengan demikian, pasar modal juga bisa di artikan sebagai pasar untuk memperjualbelikan sekuritas yang umumnya memiliki umur lebih dari satu tahun, seperti saham dan obligasi. Pasar modal dapat berfungsi juga sebagai perantara. Fungsi ini menunjukan peranan penting pasar modal dalam menunjang perekonomian karena pasar modal dapat memberikan jasanya dengan menjembatani hubungan antara pemilik modal yang di sebut sebagai pemodal (investor) dengan peminjam dan yang di sebut sebagai emiten. Menurut (Fahmi, 2013) Emiten adalah perusahaan yang terlibat dalam menjual sahamnya di pasar modal.

Sehubungan dengan perkembangan pasar modal di indonesia, banyak analisa yang muncul berkaitan dengan efesiensi informasi. Hal ini disebabkan karena pasar modal memiliki karakteristik dan daya pikat tertentu. Salah satu karakteristik pasar modal adalah adanya ketidakpastian nilai perusahaan dimasa yang akan datang, sedangkan daya pikat yang dimiliki pasar modal adalah suatu media pengumpulan dana selain perbankan dan investor dapat memilih jenis investasi berdasarkan preferensi yang diinginkan.

Harga saham merupakan faktor yang sangat penting dan harus diperhatikan oleh investor dalam melakukan investasi karena harga saham menunjukan prestasi emiten. Pergerakan harga saham searah dengan kinerja emiten, apabila emiten mempunyai prestasi yang semakin baik maka keuntungan yang didapat dan dihasilkan dari operasi usaha semakin besar (Tandelilin,2010). Harga saham juga menunjukan nilai suatu perusahaan dan merupakan indeks yang tepat untuk efektivitas perusahaan. Dengan semakin tinggi harga saham, maka semakin tinggi pula nilai perusahaan tersebut dan sebaliknya (jogiyanto, 2010).

Saham menjadi salah satu alternatif investasi di pasar modal yang paling banyak digunakan oleh para investor karena keuntungan yang diperoleh lebih besar dan dana yang dibutuhkan investor untuk melakukan investasi tidak begitu besarjika dibandingkan dengan obligasi. Tujuan perusahaan melakukan investasi saham adalah untuk memaksimalkan kesejahteraan pemegang saham dengan cara memaksimalkan nilai saham perusahaan yang pada akhirnya akan mencerminkan harga saham tersebut.

Pihak investor dapat mengetahui harga saham dan pergerakannya dengan melihat harga saham yang ada di pasar modal. Tingginya tingkat laba yang di peroleh suatu perusahaan maka akan menarik minat para investor untuk berinvestasi, karena jika perusahaan mampu memperoleh laba yang semakin besar, maka secara teoritis perusahaan akan mampu membagikan dividen. Meski perusahaan tidak harus meningkatkan pembayaran dividen jika laba yang diperoleh semakin tinggi. Sebaliknya, jika perusahaan mengalami rugi maka nilai saham akan menurun.

Investor di pasar modal berkepentingan dengan informasi kinerja perusahaan. Kinerja suatu perusahaan merupakan alat untuk mengukur prestasi kerja suatu perusahaan atau badan usaha, sehingga dapat diketahui perkembangan kondisi operasional perusahaan. Melalui penilaian kinerja, perusahaan dapat di jadikan tolak ukur landasan kebijakan yang akan di terapkan pada masa yang akan datang, sehingga tujuan utama perusahaan dapat di wujudkan. Adapun salah satu parameter kinerja tersebut adalah laporan keuangan. Laporan keuangan suatu perusahaan merupakan gambarkan tentang kondisi keuangan suatu perusahaan (Fahmi, 2013). Laporan keuangan yang di pakai untuk menilai kinerja perusahaan adalah laporan laba. Pentingnya informasi laba secara tegas telah di sebutkan dalam PSAK (2002:25) yaitu : Laporan laba rugi merupakan laporan utama untuk melaporkan kinerja suatu perusahaan selama suatu periode tertentu.

Salah satu karakteristik kualitatif dari informasi laba adalah nilai kemampuannya dalam memprediksi harga saham. Reaksi pasar terhadap harga saham akan tercermin dalam pergerakan harga saham di sekitar tanggal pengumuman informasi laba. Harga saham cenderung naik apabila laba yang dilaporkan lebih besar dan sebaliknya.

Bentuk tindakan lain dalam pelaporan keuangan adalah dengan melaporkan arus kas. Laporan arus kas merupakan laporan yang memberikan informasi yang relevan mengenai penerimaan dan pengeluaran kas dalam periode waktu tertentu. Setiap perusahaan dalam menjalankan operasi usahanya akan mengalami arus kas masuk (cash inflows) dan arus kas keluar (cash outflows). Arus kas dari aktivitas operasi terutama diperoleh dari aktivitas penghasil utama pendapatan perusahaan.

Laporan arus kas digunakan oleh manajemen untuk mengevaluasi kegiatan operasional yang telah berlangsung dan digunakan untuk merencanakan aktivitas pendanaan dimasa yang akan datang.(Miranti, 2017) dalam penelitiannya menguji pengaruh laba bersih dan arus kas terhadap 
harga saham pada sektor perbankan yang terdaftar pada indeks LQ 45 Bursa Efek Indonesia periode 2011-2015. Hasil penelitiannya menunjukan bahwa laba bersih dan arus kas operasi mempunyai pengaruh positif terhadap harga saham. Study ini juga menemukan bahwa arus kas investasi dan arus kas pendanaan tidak memiliki kemampuan untuk mempengaruhi harga saham karena hasil penelitian menunjukkan bahwa tidak ada pengaruh yang sighifikan terhadap harga saham.

(Satria, 2016) dalam penelitiannya menguji pengaruh laba akuntansi dan komponen arus kas terhadap harga saham pada industri properti yang terdaftar di Bursa Efek Indonesia tahun 20102014. Hasil penelitiannya menjelaskan bahwa laba akuntansi tidak berpengaruh signifikan terhadap harga saham. Penelitian ini juga menunjukan bahwa arus kas operasi berpengaruh signifikan terhadap harga saham sedangkan arus kas investasi dan arus kas pendanaan tidak berpengaruh signifikan terhadap harga saham pada perusahaan properti yang terdaftar di Bursa Efek Indonesia tahun 2010-2014.

(Rachmawati, 2016) dalam penelitiannya menguji pengaruh arus kas operasi dan laba akuntansi terhadap return saham. Hasil penelitiannya menunjukan bahwa berdasarkan uji parsial (uji t) Arus Kas operasi (X1) dan Laba akuntansi (X2) tidak berpengaruh signifikan terhadap return saham.seangkan dengan uji simultan, arus kas operasi dan laba akuntansi secara bersama-sama tidak berpengaruh signifikan terhadap retun saham.

Dari uraian di atas dan berdasarkan hasil penelitian terdahulu yang dengan hasil yang tidak konsisten, maka penulis tertarik untuk meneliti lebih lanjut dengan mengangkat judul tentang “ Pengaruh Laba Akuntansi dan Arus Kas operasi terbadap Harga Sabam pada Perusabaan aneka industri yang terdaftar di Bursa Efek Indonesia (BEI) tabun 2015-2017”

\section{KAJIAN PUSTAKA Pasar Modal}

Menurut Husnan Suad (2005;3) mendefinisikan bahwa pasar modal sebagai pasar untuk berbagai instrumen keuangan (atau sekuritas) jangka panjang yang bisa diperjualbelikan, baik dalam bentuk hutang maupun modal sendiri, baik yang diterbitkan pemerintah, public authorities, maupun perusahaan swasta.

Sedangkan menurut rusdin, (2008;1), pasar modal merupakan kegiatan yang berhubungan dengan penawaran umum dan perdagangan efek, perusahaan publik yang berkaitan dengan efek. Pasar modal bertindak sebagai penghubung antara para investor dengan perusahaan ataupun institusi pemerintah melalui perdagangan instrumen keuangan jangka panjang seperti obligasi, saham, dan lainnya.

Tjiptono Darmadji dan Hendy M. Fakhruddin (2006:1) menyatakan bahwa pasar modal adalah pasar untuk berbagai instrumen keuangan jangka panjang yang diperjual belikan, baik dalam bentuk utang, ekuitas (saham), instrumen derivatif, maupun instrumen lainnya. Pasar modal merupakan sarana pendanaan bagi perusahaan maupun institusi lain (misalnya pemerintah) dan sarana bagi kegiatan berinvestasi.

Pasar modal adalah instrumen keuangan yang memperjual belikan surat-surat berharga berupa obligasi dan equitas atau saham untuk jangka panjang yang di terbitkan oleh pemerintah maupun perusahaan swasta, dan kegiatannya dilaksanakan di bursa dimana tempat bertemunya investor dan emiten.

Menurut Tendelilin (2001:39) yang dikutip oleh (Rachmawati, 2016) jenis sekuritas yang di perjual belikan dipasar modal adalah sebagai berikut: (1) Saham Biasa, (2) Saham Preferent, (3) Obligasi, (4) Obligasi Konversi, (5) Right Issue, (6) Waran, dan (7) Reksadana.

\section{Pengertian Saham}

Menurut Husnan Suad (2008;29) saham adalah secarik kertas yang menunjukan hak pemodal yaitu pihak yang memiliki kertas tersebut untuk memperoleh bagian dari prospek atau kekayaan organisasi yang menerbitkan sekuritas tersebut, dan berbagai kondisi yang memungkinkan pemodal tersebut menjalankan haknya.

Menurut Dahlan (2010) yang dikutip oleh (Solehah, 2016) Mendefinisikan saham sebagai surat bukti atau tanda kepemilikan sebagai modal pada suatu perseroan terbatas. 
Saham meruapakan salah satu instrumen pasar keuangan yang paling populer diantara instrumen-instrumen pasar modal lainnya. Menerbitkan saham merupakan salah satu pilihan perusahaan ketika memutuskan untuk pendanaan perusahaan. Pada sisi yang lain, saham merupakan instrumen investasi yang banyak dipilih para investor karena saham banyak memberikan tingkat keuntungan yang menarik.

Wujud saham adalah selembar kertas yang menerangkan bahwa pemilik kertas itu adalah pemilik perusahaan yang menerbitkan kertas tersebut. Jadi sama dengan menabung di bank, setiap kali kita menabung maka kita akan mendapatkan slip yang menjelaskan bahwa kita telah menyetor sejumlah uang. Dalam investasi saham, maka kita terima bukan slip melainkan saham.

\section{Jenis-Jenis Saham}

\section{Saham Biasa}

Saham Biasa merupakan pemilik sebenarnya dari perusahaan. Mereka menanggung resiko dan mendapatkan keuntungan. Pada saat kondisi perusahaan tidak baik, mereka tidak menerima dividen. Dan sebaliknya, pada saat kondisi perusahaan baik, mereka dapat memperoleh dividen yang lebih besar bahkan saham bonus. Pemegang saham biasa ini memiliki hak suara dalam RUPS (Rapat Umum Pemegang Saham) dan ikut menentukan kebijakan perusahaan. Jika perusahaan dilikuidasi, pemegang saham biasa akan membagi sisa aset perusahaan setelah dikurangi bagian pemegang saham preferen.

Karakteristik saham biasa adalah sebagai berikut :

a) Hak suara pemegang saham, dapat memilih dewan komisaris.

b) Hak didahulukan, bila organisasi penerbit menerbitkan saham baru.

c) Tanggung jawab terbatas, pada jumlah yang diberikan saja.

\section{Saham Preferen}

Saham preferen ini mendapatkan hak istimewa dalam pembayaran dividen dibanding saham biasa.Karakteristik saham preferen adalah sebagai berikut :

a) Memiliki berbagai tingkat, dapat diterbitkan dengan karakteristik yang berbeda.

b) Tagihan terhadap aktiva dan pendapatan, memiliki prioritas lebih tinggi dari saham biasa dalam hal pembagian dividen.

c) Dividen kumulatif, bila belum dibayarkan dari periode sebelumnya maka dapat dibayarkan pada periode berjalan dan lebih dahulu dari saham biasa.

d) Konterbilitas, dapat di tukar menjadi saham biasa, bila kesepakatan antara pemegang saham dan organisasi penerbit terbentuk.

\section{Harga Saham}

Menurut Darmaji dan Fakhrudin (2012;102) Harga saham terjadi di bursa pada waktu tertentu. Harga saham bisa berubah naik ataupun turun dalam hubungan waktu yang begitu cepat. Harga saham dapat berubah dalam hitungan menit bahkan dapat berubah dalam hitungan detik. Hal tersebut dimungkinkan karena tergantung permintaan dan penawaran antara pembeli dengan penjual saham.

Menurut Tandelilin (2010;133) Harga saham merupakan cerminan dari ekspektasi investor terhadap faktor-faktor earning, aliran kas dan tingkat return yang diisyaratkan investor, yang mana ketiga faktor tersebut juga sangat dipengaruhi oleh kinerja ekonomi makro.

Berdasarkan uraian diatas dapat disimpulkan bahwa harga saham adalah harga selembar kertas yang diperjualbelikan di pasar modal, yang mana harga tersebut dapat berubah kapan saja dan berubah sesuai dengan permintaan dan penawaran serta kinerja ekonomi mikro dan makro.

\section{Penilaian Harga Saham}

Menurut Darmaji dan Fakhrudin $(2012 ; 102)$ selembar saham mempunyai nilai atau harga dan dapat dibedakan menjadi tiga yaitu:

1. Harga Nominal

Harga Nominal merupakan nilai yang tertera pada lembaran surat saham yang besarannya 
ditentukan dalam anggaran dasar perusahaan. Harga nominal sebagian besar merupakan harga dugaan yang rendah, yang secara arbitrer dikenakan atas saham perusahaan. Harga ini berguna untuk menentukan harga saham yang dikeluarkan. Besarnya harga nominal memberikan arti penting saham karena dividen minimal biasanya ditetapkan berdasarkan nilai nominal.

2. Harga Perdana

Harga ini merupakan harga yang dicatat pada bursa efek. Harga saham pada pasar perdana biasanya di tetapkan oleh penjamin emisi dan emiten. Dengan demikian akan diketahui berapa harga saham emiten itu akan dijual kepada masyarakat.

3. Harga Pasar

Harga ini merupakan harga yang ditetapkan di bursa efek bagi saham perusahaan publik atau estimasi harga untuk perusahaan yang tidak memiliki saham. Dalam bursa saham, angka ini berubah setiap hari sebagai respon terhadap hasil aktual sebagaimana tercermin dalam indeks bursa saham. Hal ini juga menunjukan bahwa tujuan utama manajemen adalah menjamin harga sebaik mungkin dalam kondisi apapun.

\section{Faktor-Faktor yang mempengaruhi Harga saham}

Menurut Irham fahmi (2013:87) ada beberapa kondisi dalam situasi yang menentukan suatu usaha saham itu akan mengalami fluktuasi, yaitu :

1. Kondisi mikro dan makro ekonomi

2. Kebijakan perusahaan dalam memutuskan untuk ekspansi (peluasam usaha), seperti membuka kantor cabang, kantor cabang pembantu baik yang dibuka di dalam maupun luar negeri.

3. Pergantian direksi secara tiba-tiba

4. Adanya direksi atau pihak komisaris perusahaan yang terlibat tindak pidana dan kasusnya sudah masuk ke pengadilan.

5. Kinerja perusahaan yang terus mengalami penurunan dalam setiap waktunya.

6. Risiko sistematis, yaitu suatu bentuk risiko yang terjadi secara menyeluruh dan telah ikut menyebabkan perusahaan ikut terlibat.

7. Efek dari psikologi pasar yang ternyata mampu menekan kondisi teknikal jual beli saham.

\section{Pengertian Laba Akuntansi}

Laba akuntansi merupakan perbedaan antara realisasi penghasilan yang berasal dari transaksi perusahaan pada periode tertentu dikurangi dengan biaya yang dikeluarkan untuk mendapatkan penghasilan tersebut.Laba Akuntansi Menurut Suwardjono (2005:460) yang dikutip kembali oleh (Yatmi, 2016) Adalah Laba dari perekayasaan akuntansi atau kesatuan usaha karena keperluan untuk menyajikan informasi secara objektif dan terandalkan. Laba Akuntansi terjadi ketika pendapatan/penjualan dalam posisi yang lebih tinggi dari pada beban dalam laporan laba rugi pada suatu periode akuntansi perusahaan.

Menurut belkaoui (2000:332) yang dikutip kembali oleh (Rizal, 2016) yang dikutip oleh laba akuntansi secara operasional didefinisikan sebagai perbedaan yang direalisasikan dan transaksi yang terjadi selama satu periode dengan biaya yang berkaitan dengan pendapatan tersebut. Laba seperti yang dijelaskan dalam statement of financial concept (FASB) yang dikutip kembali oleh (Rachmawati, 2016) adalah pengertian yang sama dengan laba bersih (Net Income) yang berlaku dalam praktek saat ini, yaitu semua laba untuk satu periode. Meski demikian, FASB membedakan konsep laba dengan laba bersih.

\section{Karakteristik laba akuntansi}

Laba menurut (belkaoui,2000) mengandung lima karakteristik yaitu :

1. Laba akuntansi didasarkan pada transaksi yang benar-benar terjadi yaitu timbulnya pendapatan dan biaya untuk mendapatkan pendapatan tersebut.

2. Laba akuntansi didasarkan pada postulat "periodik" laba, artinya merupakan prestasi perusahaan dalam bidang keuangan pada periode tertentu.

3. Laba akuntansi didasarkan pada prinsip revenue yang memerlukan pengukuran dan pengakuan.

4. Laba akuntansi memerlukan perhitungan terhadap biaya dalam bentuk biaya historis yang dikeluarkan perusahaan. 
5. Laba akuntansi didasarkan pada prinsip "matching" artinya hasil pendapatan dikurangi biaya yang dikeluarkan dalam periode yang sama.

\section{Konsep Laba Akuntansi}

Laba dari sisi akuntansi didefinisikan sebagai selisih antara harga penjualan dan biaya produksi.

Pada laba akuntansi dikenal konsep Replacemen Cost Income dengan dua komponen laba yaitu :

1. Current Operating Profit : perhitungan dari pengurangan biaya pengganti (replacemen cost) dari penghasilan.

2. Realized holding gain and loss : Perhitungan dari perbedaan antara replacemen cost barang yang dijual dengan biaya historis barang yang sama.

\section{Tujuan pelaporan Laba}

Tujuan dari pelaporan laba adalah memberikan informasi yang berguna bagi mereka yang paling berkepentingan dalam laporan keuangan.Menurut Harahap (2011:300) ada beberapa tujuan pelaporan laba adalah sebagai berikut:

1. Perhitungan Pajak, berfungsi sebagai dasar pengenaan pajak yang akan diterima negara.

2. Menghitung dividen yang akan dibagikan kepada pemilik dan yang akan ditahan dalam perusahaan.

3. Menjadi pedoman dalam menentukan investasi dan pengambilan keputusan.

4. Menjadi dasar dalam peramalan laba maupun kejadian ekonomi perusahaan lainnya di masa yang akan datang.

5. Menjadi dasar dalam perhitungan dan penilaian efisiensi.

\section{Jenis Laba Akuntansi}

Menurut Anis Chairi (2003:130) terdapat penyataan secara implisit, bahwa laporan laba rugi harus memuat informasi mengenai laba kotor, laba operasi dan laba bersih.Berdasarkan tingkatannya, terdapat tiga jenis laba yaitu:

1. Laba Kotor (Gross Profit)

Laba Kotor adalah selisih dari pendapatan perusahaan atau penjualan dikurangi dengan biaya barang yang terjual atau harga pokok penjualan. Pada umumnya laba kotor dapat dihitung sebagai berikut :

$\begin{array}{ll}\text { Penjualan (sales) } & \mathrm{xxx} \\ \text { Retur Penjualan (sales Return) } & \mathrm{xxx} \\ \text { Potongan Penjualan (Sales Discount) } & \underline{\mathrm{xxx}}- \\ \text { Penjualan Bersih (Net Sales) } & \mathrm{xxx} \\ \text { Harga pokok penjualan (COGS) } & \underline{\mathrm{xxx}}- \\ \text { Laba Kotor (Gross Profit) } & \mathrm{xxx}\end{array}$

Pelaporan laba kotor dalam laporan laba rugi menyediakan alat untuk mengevaluasi kinerja dan memprediksi pendapatan dimasa depan.

2. Laba Operasi (Operating Profit)

Angka Laba operasi adalah selisih laba kotor dengan biaya-biaya operasi. Biaya-biaya operasi adalah biaya-biaya yang berhubungan dengan operasi sehari-hari perusahaan. Beberapa perusahaan mengelompokan biaya operasimenjadi beban penjualan (selling expense) dan beban administrasi (administrative expense). Beban penjualan merupakan semua beban yang dikeluarkan perusahaan terkait dengan aktivitas penjualnnya, misal saja promosi, beban pengangkutan produk, beban gaji pegawai penjualan, dan lain-lain. Pada dasarnya format laba operasi adalah sebagai berikut:
Laba Kotor (Gross Profit)
$\operatorname{xxx}$
Beban Operasi (Operating Expense)
Laba Operasi
$\underline{\mathrm{xxx}}-$
$\mathrm{xxx}$

3. Laba Bersih (Net Income)

Laba bersih adalah selisih antara total pendapatan dikurangi dengan total biaya, dengan kata lain, laba bersih merupakan selisih laba operasi dikurangi dengan biaya bunga dan pajak penghasilan (PPh). Menurut (Wild, 2007) menyatakan bahwa yang dimaksud dengan laba bersih adalah 
komponen dalam laporan laba rugi yang terletak di baris akhir laporan. Dengan demikian laba bersih adalah laba yang dibagikan sebagian dalam bentuk dividen dan sisanya merupakan laba ditahan bagi perusahaan yang bersangkutan.

Laba Operasi (Operating Profit)

$\mathrm{xXX}$

Biaya Bunga (Interest Expense)

$\mathrm{XXX}$

Pajak Penghasilan (PPh)

Laba Bersih (Net Income)

$\underline{\operatorname{xxx}}-$

$\operatorname{xxx}$

Menurut Febrianto dan Widiastuty (2005) ketiga angka laba akuntansi tersebut bermanfaat untuk pengukuran efesiensi manajer dalam mengolah perusahaan.

\section{Pengertian Arus Kas}

Arus kas (cash flow) adalah suatu laporan keuangan yang berisikan pengaruh kas dari kegiatan operasi, kegiatan transaksi pembiayaan/pendanaan serta kenaikan atau penurunan bersih dalam kas suatu perusahaan selama satu periode. Menurut PSAK No. 2 (2002:5) arus kas adalah arus masuk dan arus keluar kas atau setara kas. Laporan arus kas merupakan revisi darimana uang kas diperoleh perusahaan dan bagaimana mereka membelanjakannya. Laporan arus kas merupakan ringkasan dari penerimaan dan pengeluaran kas perusahaan selama periode tertentu (biasanya satu tahun buku).

Laporan Arus kas (cash flow) mengandung dua macam aliran/arus kas yaitu :

\section{Cash inflow}

Cash inflow adalah arus kas yang terdiri dari kegiatan transaksi yang melahirkan keuntungan kas (penerimaan kas). Arus kas masuk (cash inflow) terdiri dari :

a. Hasil penjualan produk/jasa perusahaan.

b. Penagihan piutang dari penjualan kredit.

c. Penjualan aktiva tetap yang ada.

d. Penerimaan investasi dari pemilik atau saham bila perseroan terbatas.

e. Pinjaman/hutang dari pihak lain.

f. Penerimaan sewa dan pendapatan lain.

\section{Cash out flow}

Cash out flow adalah arus kas yang terjadi dari kegiatan transaksi yang mengakibatkan beban pengeluaran kas. Arus kas keluar (cash out flow) terdiri dari :
a. Pengeluaran biaya bahan baku, tenaga kerja langsung dan biaya pabrik lain-lain.
b. Pengeluaran biaya administrasi umum dan administrasi penjualan.
c. Pembelian aktiva tetap.
d. Pembayaran hutang-hutang perusahaan.
e. Pembayaran sewa, pajak, dividen, bunga dan pengeluaran lain-lain.

\section{Klasifikasi Laporan Arus Kas}

Klasifikasi menurut aktivitas memberikan informasi yang memungkinkan para pengguna laporan untuk menilai pengaruh aktifitas terhadap posisi keuangan perusahaan serta jumlah kas dan setara kas. Berikut klasifikasi arus kas, yaitu :

\section{Aktivitas Operasi}

Menurut PSAK No. 2 Aktivitas Operasi adalah jumlah arus kas yang berasal dari aktivitas operasi merupakan indikator yang menentukan apakah dari operasinya perusahaan dapat menghasilkan arus kas yang cukup untuk melunasi pinjaman, memelihara kemampuan operasi perusahaan membayar dividen dan melakukan investasi baru tanpa mengandalkan pada sumber pendanaan dari luar.

Menurut Prastowo (2011:34) Aktivitas operasi adalah aktivitas penghasilan utama pendapatan perusahaan (principal revenue producting activities) dan aktivitas lain yang bukan merupakan aktivitas investasi dan pendanaan. Arus kas dari aktivitas operasi mencakup semua efek kas dari setiap transaksi atau kejadian yang merupakan komponen penentuan laba bersih.Bagian aktivitas operasi sebenarnya sederhana hanya perbedaan antara kas yang diterima dan kas yang di bayarkan untuk aktivitas operasi.

Contoh arus kas dari aktivitas operasi adalah :

1. Kas masuk 
a. Penerimaan kas dari penjualan barang

b. Penerimaan kas dari penjualan jasa

c. Penerimaan kas dari royalti, komisi dan pendapatan lainnya yang diterima tunai.

2. Kas Keluar

a. Pembayaran kas kepada pemasok barang

b. Pembayaran kas kepada karyawan

c. Pembayaran kas kepada pemasok jasa lainnya.

Menurut Hery (2013) ada dua metode yang dapat di gunakan dalam menghitung dan melaporkan jumlah arus kas bersih dari aktivitas operasi, yaitu metode langsung dan metode tidak langsung. Pilihan antara metode langsung atau metode tidak langsung bukanlah sebagai suatu cara untuk memanipulasi jumlah kas yang dilaporkan dari aktivitas operasi. kedua metode tersebut akan menghasilkan angka kas yang sama. Namun, metode yang paling sering digunakan dalam praktek pelaporan keuangan adalah metode tidak langsung.

Metode Langsung (atau disebut juga metode laporan laba rugi) pada hakekatnya adalah menguji kembali setiap item (komponen) laporan laba rugi dengan tujuan untuk melaporkan berapa besar kas yang diterima atau yang dibayarkan terkait dengan setiap komponen dari laporan laba rugi tersebut. Sebagai contoh, besarnya penjualan yang tersaji dalam laporan laba rugi akan diuji kembali dengan menggunakan laporan arus kas untuk mengetahui berapa besarnya uang kas yang telah diterima dari pelanggan sepanjang periode. Demikian juga besarnya harga pokok penjalan yang akan diuji kembali untuk mengetahui berapa besarnya uang kas yang telah dibayarkan ke supplier sepanjang periode untuk membeli barang dagangan. Untuk beban gaji/upah, beban bunga, beban pajak penghasilan, dan beban-beban lainnya yang tersaji dalam laporan laba rugi juga akan diuji kembali untuk mengetahui berapa besarnya uang kas yang benar-benar telah dibayarkan atas bebanbeban tersebut.

Metode tidak langsung (atau disebut juga metode rekonsiliasi) dimulai dengan angka laba /rugi bersih sebagaimana yang dilaporkan dalam laporan laba rugi dan menyesuaikan besarnya laba/rugi bersih tersebut (yang telah diukur atas dasar akrual) dengan item-item yang tidak mempengaruhi arus kas. Dengan kata lain, besarnya laba/rugi bersih sebagai hasil dari akuntansi akrual akan disesuaikan (direkonsiliasi) untuk menentukan jumlah arus kas bersih dari aktivitas operasi. penyesuaianpenyesuaian tersebut terdiri atas :

a. Pendapatan dan beban yang tidak melibatkan arus kas masuk atau arus kas keluar, contohnya adalah amortisasi premium/diskonto investasi obligasi, beban penyisihan piutang ragu-ragu, beban penyusutan akiva tetap, beban amortisasi aktiva tidak berwujud, dan beban amortisasi premium/diskonto utang obligasi.

b. Keuntungan dan kerugian yang terkait dengan aktivitas investasi atau pembiayaan, contohnya adalah keuntungan/kerugian penjualan aktiva tetap, keuntungan/kerugian penjualan investasi dalam saham, dan keuntungan/kerugian atas penebus kembali utang obligasi.

c. Perubahn dalam aktiva lanar (selain kas) dan kewajiban lancar sebagai hasil dari transaksi pendapatan dan beban yng tidak mempengaruhi arus kas, contohnya adalah perubahan dalam saldo piutang usaha, persediaan barang dagang, biaya dibayar di muka, utang usaha, utang gaji/upah, utang bunga, dan utang pajak penghasilan.

\section{Aktivitas Investasi}

Menurut PSAK No. 2 Aktivitas investasi adalah perolehan dan pelepasan aset jangka panjang serta investasi lain yang tidak termasuk setara kas. Aktivitas investasi mencerminkan penerimaan dan pengeluaran kas sehubungan dengan sumber daya yang diperoleh perusahaan yang ditunjukan untuk menghasilkan pendapatan dan arus kas masa depan.

Contoh arus kas dari aktivitas investasi adalah :

1. Kas masuk

a. Penerimaan Kas dari Penjualan aset tetap

b. Penerimaan kas dari penjualan surat berharga yang berupa investasi

c. Penerimaan kas dari Penagihan pinjaman pokok jangka panjang/ pinjaman (tidak termasuk bunga jika merupakan kegiatan investasi) 
d. Penerimaan kas dari penjualan aset lainnya yang digunakan dalam kegiatan produksi (tidak termasuk persediaan)

2. Kas keluar

a. Pembayaran kas untuk mendapatkan aset tetap

b. Pembayaran kas untuk aktiva tak berwujud dan aktiva jangka panjang lain, termasuk pengembangan yang dikapitalisasikan

c. Pembayaran kas untuk pembelian investasi jangka panjang

d. Pembayaran kas untuk perolehan saham atau instrumen keuangan perusahaan lain.

\section{Aktivitas Pendanaan}

Menurut C. Horne James (2005) arus kas pendanaan adalah arus kas yang menunjukan dampak semua transaksi kas dengan para pemegang saham dan transaksi pinjaman serta pembayaran kembali dengan pihak pemberi pinjaman. Pengungkapan terpisah arus kas yang timbul dari aktivitas pendanaan perlu dilakukan sebab berguna untuk memprediksi klain terhadap arus kas masa depan oleh para pemasok modal perusahaan.

Contoh arus kas dari aktivitas pendanaan :

1. Kas masuk

a. Pengeluaran saham atau instrumen modal lainnya

b. Pengeluaran wesel

c. Penjualan obligasi

d. Pengeluaran surat hutang hipotik

e. Pinjaman lainnya

2. Kas keluar

a. Pembayaran dividen dan pembagian lainnya yang diberikan kepada pemilik

b. Pembelian saham perusahaan

c. Pelunassan pokok pinjaman

d. Pembayarn kas oleh lessee untuk mengurangi kewajiban yang berkaitan dengan sewa gedung usaha pembiayaan

\section{HIPOTESIS}

Berdasarkan latar belakang yang telah diuraikan, serta rumusan masalah dan tujuan penelitian yang telah di uraikan dalam pendahuluan, maka berikut adalah hipotesis yang dapat di ambil dalam penelitian ini :

\section{Pengaruh Laba Akuntansi Terhadap Harga Saham}

Informasi Laba Akuntansi memberikan peranan bagi investor untuk menanamkan modalnya pada suatu perusahaan. Tingginya tingkat laba yang di peroleh suatu perusahaan maka akan menarik minat para investor untuk berinvestasi dan dapat mempengaruhi harga saham. Hal ini didukung peneliti sebelumnya (Mutia, 2012) yang menyimpulkan bahwa laba akuntansi mempunyai pengaruh yang signifikan terhadap harga saham.

\section{Hipotesis 1 : Ada pengaruh laba akuntansi terhadap harga saham}

\section{Pengaruh Arus Kas Operasi Terhadap Harga Saham}

Pelaporan arus kas dari aktivitas operasi berisi informasi yang menentukan apakah dari operasi perusahaan dapat menghasilkan arus kas yang cukup untuk melunasi penjualan, memelihara kemampuan operasi perusahaan, membayar dividen, dan melakukan investasi baru tanpa mengandalkan pada sumber pendanaan dari luar. Hal ini didukung peneliti sebelumnya (Miranti, 2017) yang menyimpulkan bahwa arus kas operasi mempunyai pengaruh positif terhadap harga saham.

Hipotesis 2 : Ada pengaruh arus kas operasi terhadap harga saham

\section{Pengaruh Laba Akuntansi dan Arus Kas Operasi Terhadap Harga Saham}

Laba akuntansi yang tinggi dan arus kas operasi yang likuid mempengaruhi harga saham suatu perusahaan. Dimana jika laba akuntansi yang menunjukkan nilai tinggi akan mempengaruhi harga 
saham, sehingga harga saham pun meningkat. Begitupula dengan pengelolaan arus kas operasi yang positif mempengaruhi harga saham. Berdasarkan pernyataan tersebut, maka hipotesis dipaparkan sebagai berikut:

Hipotesis 3 : Ada pengaruh laba akuntansi dan arus kas operasi terhadap harga saham Gambar 1

Kerangka Pemikiran

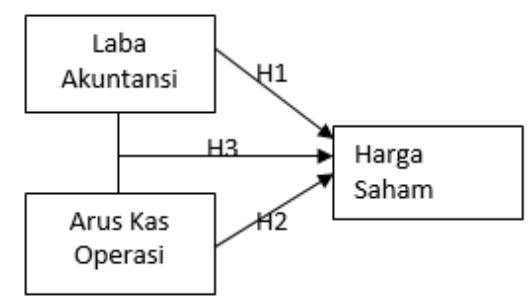

Sumber: Data diolah, 2019

\section{METODE PENELITIAN}

Lokasi penelitian dilakukan di Bursa Efek Indonesia (BEI) dengan pengambilan data laporan keuangan periode tahun 2015-2017 melalui situs resmi objek penelitian, dalam hal ini, perusahaan aneka industri yang bersangkutan dan dari beberapa situs internet yang kredible-2018. Penelitian ini menggunakan Teknik pengambilan sampel dengan purposive sampling. Purpose sampling yaitu teknik pengambilan sampel dari populasi berdasarkan suatu kriteria tertentu (Sugiyono,2013). Kriteria-kriteria dalam penelitian ini adalah laporan keuangan perusahaan aneka industri yang terdaftar di Bursa Efek Indonesia tahun 2015-2017.

Kriteria yang digunakan untuk memilih sampel adalah sebagai berikut :

1. Objek penelitian adalah Perusahaan aneka industri yang terdaftar di Bursa Efek Indonesia periode 2015-2017

2. Perusahaan aneka industri yang menerbitkan laporan keuanagan secara lengkap pada periode 2015-2017.

3. Perusahaan aneka industri yang menerbitkan annual report secara berurutan selama periode 20152017.

Berdasarkan kriteria diatas maka perusahaan yang memenuhi syarat dalam penelitian ini sebanyak 34 perusahaan aneka industri di Bursa Efek Indonesia. Penelitian dilakukan dengan menggunakan data skunder dari perusahaan selama 3 tahun. Jadi jumlah sampel observasi yang digunakan sebanyak 102 sampel.

\section{Tabel 1}

Definisi Operasional Variabel

\begin{tabular}{clll}
\hline No & \multicolumn{1}{c}{ Variabel } & \multicolumn{1}{c}{ Pengukuran } & \multicolumn{1}{c}{ Sumber } \\
\hline 1 & Laba & EAT $=$ Earning - Tax & Tandelilin 2010:19 \\
2 & Arus kas operasi & CFO $=$ CFO Masuk - CFO & Tandelilin 2010:19 \\
& Keluar & Tata-rata harga saham \\
3 & Harga saham & penutupan (closing price) $r$ & Tandelilin 2010:19 \\
& & & \\
\hline
\end{tabular}

Sumber: Data diolah penulis, 2019.

Metode Analisis data yang digunakan dalam penelitian ini adalah analisis data kuantitatif. Analisis data kuantitatif adalah metode analisis dengan angka-angka yang dapat dihitung maupun diukur, dan dalam prosesnya menggunakan alat bantu statistik. Statistik sendiri merupakan cara-cara ilmiah yang digunakan untuk mengumpulkan, mengolah, menganalisis, dan menginterpresentasikan data berupa angka-angka, kemudian menarik kesimpulan atas data tersebut, dimana data tersebut disajikan dalam bentuk tabel, grafik,atau gambar (Algifari,2003). Pengolahan data statistik dalam penelitian ini dengan menggunakan aplikasi program komputer atau software Statistica Product and Service Solution (SPSS) for Windows. 


\section{HASIL DAN PEMBAHASAN}

Objek dari penelitian ini adalah perusahaan aneka industri yang tercatat di Bursa Efek Indonesia dan mempublikasikan laporan tahunannya di website bursa efek indonesia secara konsisten dari tahun 2015-2017. Kriteria yang digunakan dalam penelitian sampel adalah perusahaan yang menerbitkan informasi mengenai harga saham, laporan laba rugi kompherensif dan laporan arus kas dalam laporan tahunannya. Populasi yang di gunaka dalam penelitian ini adalah perusahaan aneka industri yang berjumlah 41 perusahaan. Dari seluruh populasi yang ada, diambil beberapa perusahaan sebagai sampel melalui metode purpose sampling, sehingga dari 41 perusahaan aneka industri di Bursa Efek Indonesia yang memenuhi sebagai syarat sampel yaitu 34 perusahaan

Tabel 2

\section{Sampel Penelitian}

\begin{tabular}{|c|c|c|}
\hline No & Kode & Nama Perusahaan \\
\hline 1 & AMIN & Ateliers Mecaniques D'Indonesia Tbk \\
\hline 2 & KRAH & Grand Kartech Tbk \\
\hline 3 & ADMG & Polychem Indonesia Tbk \\
\hline 4 & ARGO & Argo Pantes Tbk \\
\hline 5 & ERTX & Eratex Djaya Tbk \\
\hline 6 & ESTI & Ever Shine Textile Industry Tbk \\
\hline 7 & HDTX & Panasia Indo Resources Tbk d.h Panasia Indo Syntec Tbk \\
\hline 8 & INDR & Indorama Syntetic Tbk \\
\hline 9 & PBRX & Pan Brother Tbk \\
\hline 10 & RICY & Ricky Putra Globalindo Tbk \\
\hline 11 & SRIL & Sri Rejeki Isman Tbk \\
\hline 12 & SSTM & Sunson Textile Manufacturer Tbk \\
\hline 13 & STAR & Star Petrochem Tbk \\
\hline 14 & TRIS & Trisula Internasional Tbk \\
\hline 15 & UNIT & Nusantara Inti Corpora Tbk \\
\hline 16 & BATA & Sepatu Bata Tbk \\
\hline 17 & BIMA & Primarindo Asia Infrastructure Tbk d.h Bintang Kharisma Tbk \\
\hline 18 & JECC & Jembo Cable Company Tbk \\
\hline 19 & KBLM & Kabelindo Murni Tbk \\
\hline 20 & SCCO & Supreme Cable Manufacturing and Commerce Tbk \\
\hline 21 & VOKS & Voksel Electric Tbk \\
\hline 22 & PTSN & Sat Nusa Persada Tbk \\
\hline 23 & ASII & Astra International Tbk \\
\hline 24 & AUTO & Astra Otoparts Tbk \\
\hline 25 & BRAM & Indo Kordsa Tbk d.h Branta Mulia Tbk \\
\hline 26 & GDYR & Goodyear Indonesia Tbk \\
\hline 27 & GJTL & Gajah Tunggal Tbk \\
\hline 28 & IMAS & Indomobil Sukses International Tbk \\
\hline 29 & INDS & Indospring Tbk \\
\hline 30 & LPIN & Multi Prima Sejahtera Tbk d.h Lippo Enterprises Tbk \\
\hline 31 & MASA & Multistrada Arah Sarana Tbk \\
\hline 32 & NIPS & Nipress Tbk \\
\hline 33 & PRAS & Prima Alloy Steel Universal Tbk \\
\hline 34 & SMSM & Selamat Sempurna Tbk \\
\hline
\end{tabular}

\section{Hasil Analisis Data}

Penelitian ini menggunakan outlier dan Transformasi dikarenakan adanya data yang menyimpang atau nilai yang terlalu jauh dengan yang lainnya sehingga ada 19 perusahaan (PT. Astra International Tbk, Pt. Astra Otopart Tbk, PT. Grand Kartech Tbk, PT. Indo Kordsa Tbk, PT. Indomobil Sukses International Tbk, PT. Indorama Syntetic Tbk, PT. Indospring Tbk, PT. Jembo 
Cable Company Tbk, PT. Multi Prima Sejahtera Tbk, PT. Nipress Tbk, PT. Panasia Indo Resources Tbk, PT. Ricky Putra Globalindo Tbk, PT. Sat Nusa PersadaTbk, PT. Selamat Sempurna Tbk, PT. Sepatu Bata Tbk, PT. Supreme Cable Manufacturing, PT. Gajah Tunggal Tbk, PT. Good Years Tbk, PT. Voksel Electric Tbk) yang tidak terpakai sehingga penelitian ini terdiri dari 15 sampel perusahaan pertahun atau menjadi 45 sampel selama tiga tahun.

\section{Tabel 3}

Sampel Perusahaan Setelah di Outlier dan di Transformasi

\begin{tabular}{ccl}
\hline No & Kode & \multicolumn{1}{c}{ Nama Perusahaan } \\
\hline 1 & ARGO & Argo Pantes Tbk \\
2 & AMIN & Ateliers Mecaniques D'Indonesia Tbk \\
3 & ERTX & Eratex Djaya Tbk \\
4 & ESTI & Ever Shine Textile Industry Tbk \\
5 & KBLM & Kabelindo Murni Tbk \\
6 & MASA & Multistrada Arah Sarana Tbk \\
7 & UNIT & Nusantara Inti Corpora Tbk \\
8 & PBRX & Pan Brother Tbk \\
9 & ADMG & Polychem Indonesia Tbk \\
10 & PRAS & Prima Alloy Steel Universal Tbk \\
11 & BIMA & Primarindo Asia Infrastructure Tbk d.h Bintang Kharisma Tbk \\
12 & SRIL & Sri Rejeki Isman Tbk \\
13 & STAR & Star Petrochem Tbk \\
14 & SSTM & Sunson Textile Manufacturer Tbk \\
15 & TRIS & Trisula Internasional Tbk \\
& & Sumber : www.idx.co.id, data diolah 2019
\end{tabular}

\section{Hasil Uji Statistik Deskriptif}

Menurut Gozali (2013:19) statistik deskriptif memberikan gambaran atau deskripsi suatu data yang diteliti. Dalam menggunakan statistik deskriptif suatu data dapat dilihat dari nilai rata-rata, standar deviasi,maksimum dan minimum. Statistik deskriptif digunakan untuk mempermudah ciriciri karakteristik suatu kelompok data agar mudah dipahami.Hasil analisis Deskriptif Variabel Penelitian disajikan sebagai berikut :

Tabel 4

Hasil Uji Statistik Deskriptif

\begin{tabular}{lrrrrr}
\hline & N & Minimum & \multicolumn{1}{c}{ Maximum } & \multicolumn{1}{c}{ Mean } & Std. Deviation \\
\hline Laba Akuntansi & 45 & -30657.00 & 68035.00 & 5887.4667 & 23917.70977 \\
Arus Kas Operasi & 45 & -35840.00 & 78783.00 & 13242.4667 & 25789.35056 \\
Harga Saham & 45 & 1.70 & 2.95 & 2.3648 & .31921 \\
Valid N (listwise) & 45 & \multicolumn{5}{c}{ Sumber: SPSS22, data diolah 2019. } \\
\hline \multicolumn{7}{c}{}
\end{tabular}

Dari output diatas dapat diketahui deskripsi data laba akuntansi, arus kas operasi dan harga saham.

1. Untuk data Laba Akuntansi jumlah data (N) sebanyak 45, jarak data Nilai minimum -30657 dan nilai maksimum 68035, dan mean (rata-rata) sebesar 5887,46 dan nilai standar deviasi sebesar 23917,7 .

2. Untuk data Arus Kas operasi jumlah data (N) sebanyak 45, nilai minimum -35840 dan nilai maksimum 78783, dan mean (rata-rata) sebesar -13242,46 dan nilai standar deviasi sebesar $25789,3$.

3. Untuk data Harga Saham jumlah data $(\mathrm{N})$ sebanyak 45, nilai minimum 1,70 dan nilai maksimum 2,95 dan mean (rata-rata) sebesar 2,36 dan nilai standar deviasi sebesar 0,32.

\section{Pengujian Hipotesis dan Pembahasan}

Hasil Uji Normalitas

Uji normalitas bertujuan untuk menguji apakah data variabel independen dan data variabel 
dependen pada persamaan regresi berdistribusi normal atau tidak. Uji normalitas pada penelitian ini menggunakan P-P Plot. Jika data menyebar di sekitar garis diagonal dan mengikuti arah garis diagonal atau grafik histogramnya, menunjukan pola terdistribusi normal, maka model regresi memenuhi asumsi normalitas .Menurut Duwi Priyatno (2016) data dinyatakan berdistribusi normal jika signifikan lebih besar dari 0,05 menggunakan uji Kolmogorov-Semirov. Berikut hasil uji normalitas data sebagai berikut :

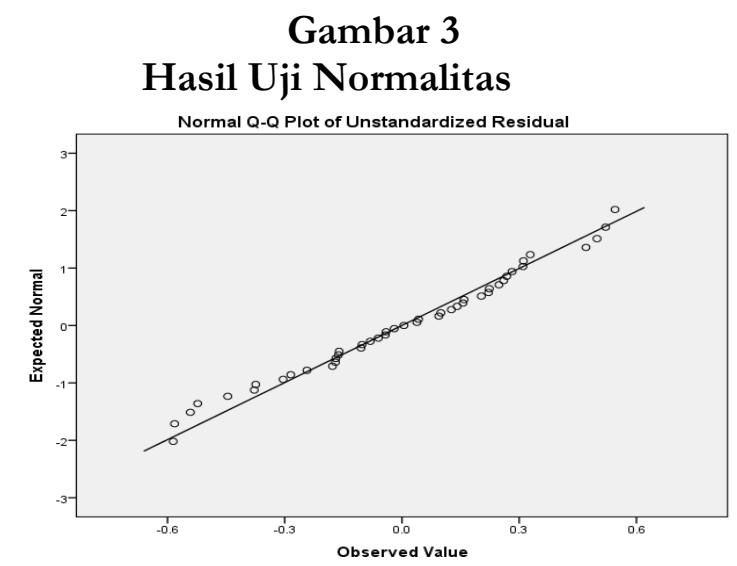

Sumber : Data Olahan SPSS V. 22

Dari Grafik diatas terlihat bahwa titik-titik berada pada garis diagonal dan mengikuti arah diagonal. Maka dapat disimpulkan bahwa pola berdistribusi normal.

Tabel 5

Hasil Uji Normalitas

One-Sample Kolmogorov-Smirnov Test

\begin{tabular}{llrrr}
\hline & & laba akuntansi & $\begin{array}{c}\text { arus kas } \\
\text { operasi }\end{array}$ & $\begin{array}{r}\text { Harga } \\
\text { Saham }\end{array}$ \\
\hline $\mathrm{N}$ & & 45 & 45 & 45 \\
Normal & Mean & 5887.4667 & 13242.4667 & 2.3648 \\
Parameters $^{\mathrm{a}, \mathrm{b}}$ & Std. Deviation & 23917.70977 & 25789.3505 & .31921 \\
& & 6 & 6 & .094 \\
Most & Absolute & .127 & .100 & .094 \\
Extreme & Positive & .127 & .100 & .073 \\
Differences & Negative & -.078 & -.059 & -.094 \\
Test Statistic & .127 & .100 & .094 \\
Asymp. Sig. (2-tailed) & $.065^{\mathrm{c}}$ & $.200^{\mathrm{c}, \mathrm{d}}$ & $.200^{\mathrm{c}, \mathrm{d}}$ \\
\hline a Test dis. & & &
\end{tabular}

a. Test distribution is Normal.

b. Calculated from data.

c. Lilliefors Significance Correction.

Sumber: SPSS22, data diolah 2019.

Dari output diatas diketahui bahwa nilai signifikansi (sig) pada kolmogorov-smirov laba Akuntansi 0,65 >0,05, Arus kas operasi 0,200 > 0,05, dan Harga saham 0,200>0,05. maka dapat disimpulkan bahwa data terdistribusi dengan normal.

\section{Hasil Uji Multikolinearitas}

Uji Multikolinearitas adalah keadaan dimana antara dua variabel independen atau lebih pada model regresi terjadi hubungan linier yang sempurna atau mendekati sempurna, karena model regresi yang baik mensyaratkan tidak adanya masalah multikolinearitas. Metode yang digunakan yaitu dengan melihat nilai inflation factor (VIF) dan Tolerance pada model regresi. Jika nilai VIF kurang dari 10 dan Tolerance lebih dari 0,1 ,maka model regresi bebas dari multikolinearitas (Duwi Priyanto,2016) 


\section{Tabel 6}

Hasil Uji Multikolinearitas

\begin{tabular}{|c|c|c|c|c|c|c|c|c|}
\hline & \multirow[t]{2}{*}{ Model } & \multicolumn{2}{|c|}{$\begin{array}{c}\text { Unstandardized } \\
\text { Coefficients }\end{array}$} & \multirow{2}{*}{$\begin{array}{c}\text { Standardized } \\
\text { Coefficients } \\
\text { Beta }\end{array}$} & \multirow[t]{2}{*}{$\mathrm{T}$} & \multirow[t]{2}{*}{ Sig. } & \multicolumn{2}{|c|}{$\begin{array}{l}\text { Collinearity } \\
\text { Statistics }\end{array}$} \\
\hline & & $\mathrm{B}$ & Std. Error & & & & Tolerance & VIF \\
\hline \multirow[t]{3}{*}{1} & (Constant) & 2.417 & .053 & & 45.327 & .000 & & \\
\hline & laba akuntansi & $1.156 \mathrm{E}-7$ & .000 & .009 & .059 & .953 & .999 & 1.001 \\
\hline & arus kas operasi & $-4.027 \mathrm{E}-6$ & .000 & -.325 & -2.228 & .031 & .999 & 1.001 \\
\hline
\end{tabular}

a. Dependent Variable: Harga Saham

Sumber: SPSS22, data diolah 2019.

Dari hasil output diatas dapat diketahui bahwa nilai VIF kurang dari 10 yaitu untuk variabel independen Laba akuntansi (X1) nilai VIF sebesar 1,001 dan variabel Arus Kas operasi (x2) nilain VIF sebesar 1,001. Dan nilai tolerance lebih dari 0,1 untuk variabel Laba Akuntansi (X1) nilai tolerance 0,999 dan variabel Arus Kas operasi sebesar 0,999. Maka dapat disimpulkan bahwa model regresi tidak terjadi masalah multikolinearitas.

\section{Hasil Uji Autokorelasi}

Menurut (Duwi Priyatno, 2016) Regresi yang baik adalah yang tidak ada masalah autokorelasi. Metode pengujian yang digunakan dalam penelitian ini adalah Durbin-Waston (Uji DW). Berikut hasil uji Autokorelasi :

\section{Tabel 7}

Hasil Uji Autokorelasi Model Summary ${ }^{\mathrm{b}}$

\begin{tabular}{rrrrrr}
\hline Model & $\mathrm{R}$ & R Square & Adjusted R Square & $\begin{array}{r}\text { Std. Error of } \\
\text { the Estimate }\end{array}$ & $\begin{array}{c}\text { Durbin- } \\
\text { Watson }\end{array}$ \\
\hline 1 & $.326^{\mathrm{a}}$ & .106 & .064 & .30890 & 1.374 \\
\hline
\end{tabular}

a. Predictors: (Constant), arus kas operasi, laba akuntansi

b. b. Dependent Variable: Harga Saham

Sumber: SPSS22, data diolah 2019.

Nilai Durbin Waston dapat dilihat pada output Regression pada tabel Model Summary. Dapat diketahui bahwa nilai Durbin waston sebesar 1,374. Sedangkan dari tabel DW dengan signifikansi 0,005 dan jumlah data $(\mathrm{n})=20$, serta $\mathrm{k}=2$ ( $\mathrm{k}$ adalah jumlah variabel independen) diperoleh nilai $\mathrm{dl}$ sebesar 1,4298 dan du sebesar 1,6148 (Lihat pada lampiran). Maka di dapat $0<\mathrm{d}<\mathrm{dl}$ atau $0<$ $1,374<1,4298$. Maka tidak terjadi autokorelasi positif.

\section{Hasil Uji Heteroskedastisitas}

Dalam pengambilan keputusan pada uji heteroskedastisitas (Duwi Priyatno,2016:117) Metode pengujian yang digunakan dalam penelitian ini adalah uji scatterplot. Uji scatterplot yaitu dengan melihat pola titik-titik pada scatterplot regresi. Jika titik-titik menyebar dengan pola yang tidak jelas di atas dan di bawah angka 0 pada sumbu Y maka tidak terjadi masalah heteroskedastisitas. Berikut adalah hasil uji heteroskedastisitas berupa scatterplot:

\section{Gambar 4}

\section{Hasil Uji Heteroskedastisitas}

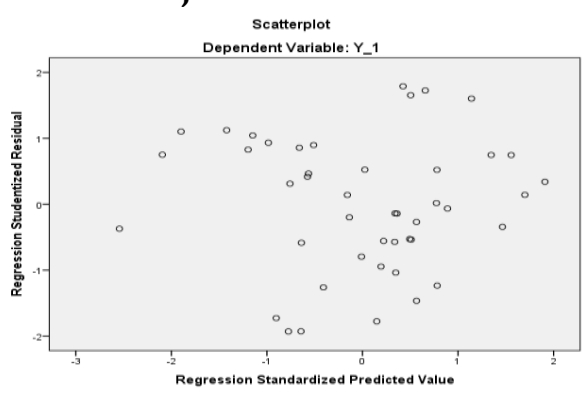

Sumber: SPSS22, data diolah 2019. 
Dari Output diatas dapat disimpulkan bahwa hasil uji heteroskedastisitas dapat diketahui bahwa titik-titik menyebar dengan pola yang tidak jelas diatas dan dibawah angka 0 pada sumbu $\mathrm{Y}$, jadi dapat disimpulkan bahwa tidak terjadi masalah heteroskedastisitas pada model regresi.

\section{Hasil Analisis Regresi Berganda}

Analisis regresi linier berganda digunakan untuk mengetahui pengaruh antara dua atau lebih variabel independen dengan satu variabel dependen yang ditampilkan dalam bentuk persamaan regresi. Berikut ini adalah persamaan regresi linier berganda :

$$
\begin{aligned}
& \mathrm{Y}=\alpha+\beta 1 X 1+\beta 2 \mathrm{X} 2+\mathrm{e} \\
& \mathrm{Y}=2,417+1,156 \mathrm{X} 1+(-4,027) \mathrm{X} 2+\mathrm{e}
\end{aligned}
$$

Keterangan :

$$
\begin{array}{ll}
\mathrm{Y} & : \text { Harga Saham } \\
\alpha & : \text { Konstanta } \\
\beta 1 \beta 2 & : \text { Koefisien regresi dari masing-masing variabel independen } \\
\mathrm{X} 1 & : \text { Laba Akuntansi } \\
\mathrm{X} 2 & : \text { Arus kas Operasi } \\
\mathrm{e} & : \text { Error }
\end{array}
$$

\section{Tabel 8}

Hasil Uji Regresi Linier Berganda

\begin{tabular}{rlrrrrr}
\hline \multirow{2}{*}{ Model } & \multicolumn{2}{c}{ Unstandardized Coefficients } & \multicolumn{2}{c}{$\begin{array}{c}\text { Standardized } \\
\text { Coefficients }\end{array}$} & \multirow{2}{*}{ T } & Sig. \\
\cline { 3 - 6 } & \multicolumn{1}{c}{ B } & \multicolumn{1}{c}{ Std. Error } & Beta & & \\
\hline 1 & (Constant) & 2.417 & .053 & & 45.327 & .000 \\
& laba akuntansi & $1.156 \mathrm{E}-7$ & .000 & .009 & .059 & .953 \\
& arus kas operasi & $-4.027 \mathrm{E}-6$ & .000 & -.325 & -2.228 & .031 \\
\hline
\end{tabular}

a. Dependent Variable: Harga Saham

Sumber: SPSS22, data diolah 2019.

Penjelasan Persamaan Berikut adalah sebagai berikut :

1. Konstanta sebesar 2,417 artinya jika Laba Akuntansi dan Arus Kas Operasi keuntungannya 0, maka harga saham nilainya sebesar 2,417.

2. Koefisien regresi variabel Laba akuntansi sebesar 1,156 artinya jika laba akuntansi mengalami kenaikan satu satuan maka harga saham akan mengalami peningkatan sebesar 1,156 satuan dengan asumsi independennya bernilai tetap.

3. Koefisisen regresi variabel arus kas operasi sebesar -4,027 artinya bia arus kas operasi mengalami kenaikan satu satuan maka harga saham akan berkurang sebesar 4,027 dengan asumsi independennya bernilai tetap.

\section{Hasil Uji Hipotesis}

\section{Hasil Uji Koefisien Determinasi $\left(\mathbf{R}^{\mathbf{2}}\right)$}

Pada model regresi linier berganda ini akan dianalisis pula besarnya koefisien determinasi $\left(\mathrm{R}^{2}\right)$ keseluruhan. Menghitung $\left(\mathrm{R}^{2}\right)$ digunakan untuk mengukur ketepatan yang paling baik dari analisis regresi linier berganda. Jika nilai $\left(\mathrm{R}^{2}\right)$ yang diperoleh mendekati 1 (satu) maka dapat dikatakan semakin kuat model tersebut dalam menerangkan variasi variabel independen terhadap variabel dependen. Sebaliknya jika nilai $\left(\mathrm{R}^{2}\right)$ mendekati angka 0 (nol) maka semakin lemah variasi variabelvariabel independen menerangkan variabel dependen.

Dalam uji regresi linier berganda ini dianalisis pula besarnya koefisien determinasi $\left(\mathrm{R}^{2}\right)$. Uji koefisien determinasi dalam penelitian ini digunakan untuk melihat besar pengaruh variabel independen (Arus kas operasi dan Laba Akuntansi) terhadap variabel dependen (Harga Saham). 


\section{Tabel 9}

\section{Hasil Uji Koefisien Determinasi $\mathbf{R}^{2}$ Model Summary ${ }^{\mathrm{b}}$}

\begin{tabular}{llrrr}
\hline Model & R & R Square & Adjusted R Square & $\begin{array}{l}\text { Std. Error of } \\
\text { the Estimate }\end{array}$ \\
\hline 1 & $.326^{a}$ & .106 & .064 & .30890 \\
\hline
\end{tabular}

a. Predictors: (Constant), arus kas operasi, laba akuntansi

b. Dependent Variable: Harga Saham

Sumber : Data diolah, 2019.

Berdasarkan output diperoleh angka R Square sebesar 0,106 atau 10,6\%. Hal ini menunjukan bahwa prosentase sumbangan pengaruh variabel independen yaitu arus kas operasi dan laba akuntansi terhadap variabel harga saham sebesar 10,6\%. Sedangkan sisanya 80,4\% dipengaruhi oleh variabel lain yang tidak diteliti dalam penelitian ini.

\section{Hasil Uji t (Uji Koefisien regresi secara parsial)}

Uji t pada regresi linier berganda yang dalam penelitian ini digunakan untuk mengetahui pengaruh variabel independen secara parsial terhadap variabel dependen. Jika probabilitas nilai $\mathrm{t}<0,05$ maka dapat disimpulkan bahwa terdapat pengaruh antara variabel bebas dan variabel terikat secara parsial. Jika nilai $\mathrm{t}>0,05$ maka dapat di simpulkan bahwa tidak terdapat pengaruh yang signifikan antara masing-masing variabel bebas terhadap variabel terikat. Berikut adalah hasil uji t dapat dilihat dalam tabel 8 diatas, dijelaskan bahwa:

\section{Pengujian koefisiensi regresi variabel Laba Akuntansi (X1)}

Langkah-langkah pengujian sebagai berikut :
a. Menentukan Hipotesis
Ho $\quad$ : Laba Akuntansi secara parsial tidak berpengaruh terhadap Harga Saham
$\mathrm{Ha} \quad$ : Laba Akuntansi secara parsial berpengaruh terhadap Harga Saham
b. Menentukan Tingkat Signifikansi
Tingkat Signifikansi menggunakan 0.05
c. Menentukan t hitung
Berdasarkan output diatas diperoleh t hitung sebesar 0,059
d. Menentukan t tabel
Tabel distribusi t dicari pada a $=5 \%: 2=2,5 \%$ (uji 2 sisi) dengan derajat kebebasan (df) n-k-1 atau $45-2-1=42$ (n adalah jumlah data dan $\mathrm{k}$ adalah jumlah variabel independen). Dengan pengujian dua sisi (signifikansi $=0.025$ ) hasil diperoleh untuk $\mathrm{t}$ tabel sebesar 2,018 (Lihat pada lampiran).
e. Kriteria penguijan
Ho diterima jika $-\mathrm{t}$ tabel $f$, $\mathrm{t}$ hitung $f$, $\mathrm{t}$ tabel
Ho ditolak jika $-\mathrm{t}$ hitung $<$-t tabel atau $\mathrm{t}$ hitung $>\mathrm{t}$ tabel
f. Membandingkan thitung dengan $t$ tabel dan probabilitas
Nilai t hitung $<\mathrm{t}$ tabel $(0,059<2,018)$ dan nilai signifikansi $0,953>0,05$ maka Ho diterima.
g. Kesimpulan
Karena t hitung $<\mathrm{t}$ tabel $(0,059<2,018)$ dan nilai signifikansi $0,935>0,05$ maka Ho diterima. Maka dapat disimpulkan bahwa Laba Akuntansi secara parsial tidak berpengaruh berpengaruh terhadap Harga saham.

\section{Pengujian koefisien regresi variabel Arus Kas Operasi (X2)}

Langkah-langkah pengujian sebagai berikut :
a. Menentukan Hipotesis
Ho : Arus Kas Operasi secara parsial tidak berpengaruh terhadap Harga Saham
$\mathrm{Ha}$ : Arus Kas Operasi secara parsial berpengaruh terhadap Harga Saham
b. Menentukan Tingkat Signifikansi 
Tingkat Signifikansi menggunakan 0.05

c. Menentukan thitung

Berdasarkan output diatas diperoleh t hitung sebesar -2,228

d. Menentukan t tabel

Tabel distribusi t dicari pada a $=5 \%: 2=2,5 \%$ (uji 2 sisi) dengan derajat kebebasan (df) $n-k-1$ atau $45-2-1=43$ ( $\mathrm{n}$ adalah jumlah data dan $\mathrm{k}$ adalah jumlah variabel independen). Dengan pengujian dua sisi (signifikansi $=0.025$ ) hasil diperoleh untuk t tabel sebesar 2,018 (Lihat pada lampiran).

e. Kriteria pengujian

Ho diterima jika $-\mathrm{t}$ tabel $f$, $\mathrm{t}$ hitung $£$, $\mathrm{t}$ tabel

Ho ditolak jika $-\mathrm{t}$ hitung $<$-t tabel atau $\mathrm{t}$ hitung $>\mathrm{t}$ tabel

f. Membandingkan $t$ hitung dengan $t$ tabel dan probabilitas

Nilai -t hitung $<$-t tabel $(-2,228<-2,018)$ dan nilai signifikansi $0,031<0,05$ maka Ho ditolak.

g. Kesimpulan

Karena nilai -t hitung $<-$ t tabel $(-2,228<-2,018)$ dan nilai signifikansi $0,031<0,05$ maka Ho di tolak. Maka dapat disimpulkan bahwa Arus Kas operasi secara parsial berpengaruh terhadap harga saham.

\section{Hasil Uji F (Uji Koefisien regresi secara bersama-sama )}

Hasil uji $F$ yang diperoleh setelah data diolah di sajikan dalam tabel berikut :

\section{Tabel 10}

Hasil Uji F (Uji koefisien regresi secara bersama-sama) ANOVA $^{a}$

\begin{tabular}{llrrrrl}
\hline & Model & Sum of Squares & Df & Mean Square & F & Sig. \\
1 & Regression & .476 & 2 & .238 & 2.493 & $.095^{\mathrm{b}}$ \\
& Residual & 4.008 & 42 & .095 & & \\
Total & 4.483 & 44 & & & \\
\hline
\end{tabular}

a. Dependent Variable: Harga saham

b. Predictors: (Constant), laba akuntansi, arus kas operasi

Sumber : Data diolah, 2019

Tahap-tahap untuk melakukan uji F sebagai berikut :

a. Menentukan hipotesis nol dan hipotesis alternatifnya

Ho $=0$

(Artinya Laba Akuntansi dan Arus Kas operasi secara bersama-sama tidak berpengaruh terhadap harga Saham)

$\mathrm{Ha}^{1} 0$

(Artinya Laba Akuntansi dan Arus Kas operasi secara bersama-sama berpengaruh terhadap Harga Saham)

b. Menentukan F hitung

Berdasarkan tabel diatas diperoleh F hitung sebesar 2,493

c. Menentukan F tabel

F tabel dapat dilihat pada lampiran statistik, dengan menggunakan tingkat signifikansi 0,05 , dengan df 1 (jumlah variabel -1 ) atau 3-1=2 dan df $2(n-k-1)$ atau 45-2-1 =42. Hasil perolehan $F$ tabel sebesar 3,220

d. Kriteria Pengujian

Ho diterima bila $\mathrm{F}$ hitung $\leq \mathrm{F}$ tabel

Ho ditolak bila Fhitung $\geq \mathrm{F}$ tabel

e. Membandingkan $\mathrm{F}$ hitung dengan $\mathrm{F}$ tabel dan probabilitas

Nilai F hitung $<$ F tabel $(2,493<3,220)$ dan nilai signifikansi $0,95>0,05$ maka Ho diterima

f. Membuat Kesimpulan

Karena F hitung $<$ F tabel $(2,493<3,220)$ dan nilai signifikansi $0,95>0,05$ maka Ho diterima, 
artinya bahwa laba akuntansi dan arus kas operasi secara bersama-sama tidak berpengaruh terhadap harga saham.

\section{KESIMPULAN DAN SARAN}

\section{Kesimpulan}

Penelitian ini bertujuan untuk menguji pengaruh Laba Akuntansi dan Arus Kas Operasi terhadap Harga saham di perusahaan aneka industri pada tahun 2015-2017. Pengujian ini menguji 2 variabel independen yaitu : Laba Akuntansi dan Arus Kas Operasi serta variabel dependen berupa Harga saham.Berdasarkan hasil analisi data dan pengujian hipotesis pada penelitian ini maka dapat diambil kesimpulannya, yaitu :

1. Laba Akuntansi tidak berpengaruh terhadap harga saham pada perusahaan aneka industri yang terdaftar di Bursa Efek Indonesia pada periode 2015-2017. Hal ini ditunjukan dari hasil perhitungan yaitu nilai koefisien regresi sebesar 1,156 dengan t-hitung sebesar 0,059 lebih kecil dari t-tabel sebesar 2,018 dan nilai signifikansi yang berada di atas 0,05 yaitu sebesar 0,953.

2. Arus Kas Operasi berpengaruh terhadap harga saham pada perusahaan aneka industri yang terdaftar di Bursa Efek Indonesia periode 2015-2017. Hal ini di tunjukan dari hasil analisis data dengan nilai koefisien regresi sebesar -4,027 dengan t-hitung (mutlak) dari -2,228 lebih kecil dari pada t-tabel sebesar -2,018 dan nilai signifikansi yang berada di bawah 0,005 yaitu sebesar 0,031.

3. Laba Akuntansi dan Arus Kas Operasi secara bersama-sama Tidak berpengaruh terhadap harga saham . Hal ini ditunjukan dengan nilai F-huting lebih kecil dari F-tabel $(2,493<3,220)$ dengan nilai signifikansi lebih besar dari 0,05 yaitu sebesar 0,95 .

\section{Saran}

Berdasarkan hasil analisis dan pembahasan serta kesimpulan penelitian, maka dapat dikemukakan beberapa saran :

1. Bagi Perusahaan

Berdasarkan penelitian laba akuntansi berpengaruh terhadap harga saham pada perusahaan aneka industri, maka untuk perusahaan yang menjadi sampel dalam penelitian ini ataupun perusahaan diluar penelitian ini diharapkan memperhatikan faktor-faktor yang mempengaruhi harga saham, salah satunya adalah laba akuntansi. Sehingga perusahaan bisa memaksimalkan kinerjanya dan menghasilkan laba yang meningkat.

2. Bagi Investor

Hasil penelitian ini bisa menjadi salah satu pertimbangan bagi investor dalam melakukan investasi dalam bentuk saham, karena dari hasil penelitian ini investor bisa memiliki landasan baru dalam pengambilan keputusan untuk berinvestasi dalam bentuk saham.

3. Bagi Peneliti Selanjutnya

a. Untuk peneliti selanjutnya di harapkan dapat menjadikan semua perusahaan yang terdaftar di Bursa Efek Indonesia menjadi sampel penelitian. Hal ini akan dapat diketahui perbedaan mengenai karakteristik perusahaan aneka industri dengan sektor lainnya.

b. Bagi peneliti selanjutnya sebaiknya menambahkan variabel penelitian agar hasil penelitian nantinya memberikan gambaran terbaru dari perusahaan yang diteliti.

\section{Keterbatasan Penelitian}

Berdasarkan dari hasil penelitian yang telah dilakukan, penelitian ini memiliki beberapa keterbatasan, diantaranya adalah sebagai berikut :

1. Banyak data yang tidak masuk kriteria pemilihan sampel dan banyak sampel yang datanya tidak bisa dipakai karena menyimpang dan terlalu jauh sehingga hanya ada 15 perusahaan yang tersisa selama tiga tahun untuk diteliti masih kurang mencukupi untuk menghasilkan suatu kesimpulan yang dapat di generalisasikan.

2. Keterbatasan dalam mengambil variabel yang digunakan dalam penelitian yaitu hanya menguji 2 variabel independen yang mempengaruhi harga saham yaitu laba akuntansi dan arus kas operasi. 


\section{DAFTAR PUSTAKA}

Algifari. (2003). Statistika Induktif Untuk Ekonomi dan Bisnis. Yogyakarta: AM YKPN.

Anis, C. d. (2003). Teori Akuntansi. Semarang: Universitas Diponegoro.

Belkaoui, A. (2007). Accounting Theory. 5Th Edition (Buku 2 Edisi terjemahan ed.). Jakarta, Salemba Empat.

Darmadji, T. d. (2006). Pasar Modal di Indonesia (Edisi 2 ed.). Jakarta: Salemba Empat.

Darmadji, T. d. (2012). Pasar Modal di Indonesia (Edisi Ketiga ed.). Jakarta: Salemba Empat.

Fahmi, I. (2012). Analisis Laporan Kenangan. Bandung: Alfabeta.

Fahmi, I. (2013). Pengantar Pasar Modal. Bandung: Alfabeta.

Fauzi, M. (2009). Metode Penelitian Kuantitatif. Semarang: Walisongo Press.

Fauzi, M. (2009). Metode Penelitian Kuantitatif. Semarang: Walisongo Press.

Febrianto, R. W. (2005). Tiga Laba Akuntansi : Mana yang lebih bermakna bagi investor. Simposium National Akuntansi, 159-169.

Ghozali, I. (2005). Aplikasi Multivariate dengan program SPSS. Semarang: Badan Penleiti UNDIP.

Gozali, I. (2011). Aplikasi Analisis Multivariate dengan Program IBM SPSS19 (Edisi Kelima ed.). Semarang: UNDIP.

Gozali, I. (2002). Aplikasi Analisis Multivariate dengan Program SPSS (Edisi 4 ed.). Semarang: UNDIP.

Gozali, I. (2013). Aplikasi Analisis Multivariate dengan Program SPSS (Edisi Ketujuh ed.). Semarang: Badan Penerbit Universitas diponegoro.

Harahap, S. S. (2011). Analisis Kritis Atas Laporan Kenangan. Jakarta: Raja Grafindo Persada.

Hery. (2013). Dasar-Dasar Akuntansi. Jakarta: CAPS.

Horne, J. (2005). Prinsip-prinsip Manajemen Kenangan (Buku 2, Edisi 13 ed.). Jakarta: Salemba Empat.

IAI. (2002). Standar akuntansi Keuangan. Jakarta: Salemba Empat.

Jogiyanto, H. (2010). Teori Portofolio dan Analisis Investasi (Edisi ketujuh ed.). Yogyakarta: BPFE.

Miranti. (2017). Pengaruh Laba Bersih dan Arus Kas terhadap harga saham pada sektor perbankan yang terdaftar pada indeks LQ 45 Bursa Efek Indonesia Periode 2011-2015. Jurnal ilmiah akuntansi bisnis \& keuangan vol. 9, No. 2.

Mutia, E. (2012). Pengaruh Informasi Laba dan Arus Kas Terhadap Harga Saham perusahaan LQ45 di Bursa Efek Indonesia periode 2007-2009. Jurnal Akuntansi, vol. 1, No.1, 12-22.

Priyatno, D. (2016). SPSS Handbook Analisis data, Olah Data, dan Penyelesaian Kasus-kasus Statistik. Media kom.

Rachmawati, R. (2016). Pengaruh Arus Kas Opeasi dan Laba Akuntansi terhadap Retun Saham. AKTIV A Jurnal Akuntansi dan Investasi, Vol.1, No 2.

Rizal, N. A. (2016). Pengaruh Laba Akuntansi Dan Arus Kas Serta Ukuran Perusahaan Terhadap Return Saham (Studi Empiris Pada Perusahaan Perbankan yang Terdaftar di BEI Tahun 20122014). Jurnal Spread, Vol. 6 No.2.

Rusdin. (2008). Pasar Modal Cetakan Kedua. Bandung: Alfabeta.

Satria, D. I. (2016). Pengaruh Laba Akuntansi dan Komponen Arus Kas terhadap Harga Saham Pada Industri Properti yang terdaftar di Bursa Efek Indonesia. Jurnal Akuntansi dan Keuangan Vol. 5, No.1.

Sekaran, U. (2006). Metodologi Penelitian Untuk Bisnis (Edisi 4 Buku 1 ed.). Jakarta: Salemba Empat.

Sekaran, U. (2006). Metodologi Penelitian Untuk Bisnis (Edisi 4, Buku 1 ed.). Jakarta: Salemba Empat.

Solehah, S. A. (2016). Pengaruh Komponen Arus Kas dan Pertumbuhan Penjualan Terhadap Harga saham Serta Struktur Modal Sebagai Variabel Intervening (Study kasus pada perusahaan Textile dan Garmen yang terdaftar di Bursa Efek Indonesia Periode 2010-2015). Fakultas Ekonomi dan Bisnis Universitas Pandanaran .

Suad, H. (2005). Dasar-dasar Teori Portofolio dan Analisis Sekuritas (Edisi Kelima ed.). Yogyakarta: BPFE.

Suad, H. (2008). Manajemen Kenangan: Teori dan Penerapan (Buku 1, Edisi 4 ed.). Yogyakarta: BPFE.

Sugiyono. (2003). Metode Penelitian Bisnis. Bandung: Alfabeta.

Sugiyono. (2013). Metode Penelitian Kombinasi (Mixed Methode). Bandung: Alfabeta.

Sugiyono. (2009). Metode Penelitian Kuantitatif, Kualitatif dan R\&D. Jakarta: Salemba Empat.

Sugiyono. (2012). Metode Penelitian Kuantitatif, Kualitatif dan R\&D. Bandung: Alfabeta. 
Sulistyani, N. (2017). Pengaruh Kinerja Keuangan Terhadap Harga Saham Perusahaan Property and real estate yang terdaftar di BEI. Jurnal Ilmu dan Riset Manajemen Vol. 6, No. 11 .

Tandelilin, E. (2001). Analisis Investasi dan Manajemen Portofolio (Edisi Pertama ed.). Yogyakarta: PT. BPFE Yogyakarta.

Tandelilin, E. (2010). portofolio dan investasi Teori dan Aplikasi (Edisi Pertama ed.). Yogyakarta: Kanisius.

Untung, B. (2011). Hukum Bisnis Pasar Modal. Yogyakarta: ANDI.

Wild, S. F. (2007). Financial Statement Analysis (Edisi 12 ed.). Jakarta: Erlangga.

Yatmi, M. A. (2016). Pengaruh Laba Akuntansi dan Good Corvorate Governance Terhadap Return Saham Perusahaan Peserta Corporate Governance Perception Index. Jurnal Akuntansi dan Sistem Teknologi Informasi, Vol.12 No.2, 193-199.

http://www.idx.co.id/ di akses tanggal 01 Juli 2018

http://www.sahamok.com/perusahaan-aneka-industri-di-bei/ diakses tanggal 01 Juli 2018 